\title{
Effects of preoperative feeding with a whey protein plus carbohydrate drink on the acute phase response and insulin resistance. A randomized trial
}

Francine Perrone1, Antônio C da-Silva-Filho', Isa F Adôrno ${ }^{1}$, Nadia T Anabuki ${ }^{1}$, Fernando S Leal', Tariane Colombo ${ }^{1}$, Benedito D da Silva', Diana B Dock-Nascimento ${ }^{1}$, Aderson Damião ${ }^{1}$ and José E de Aguilar-Nascimento ${ }^{1,2^{*}}$

\begin{abstract}
Background: Prolonged preoperative fasting increases insulin resistance and current evidence recommends carbohydrate $(\mathrm{CHO})$ drinks 2 hours before surgery. Our hypothesis is that the addition of whey protein to a CHObased drink not only reduces the inflammatory response but also diminish insulin resistance.

Methods: Seventeen patients scheduled to cholecystectomy or inguinal herniorraphy were randomized and given $474 \mathrm{ml}$ and $237 \mathrm{ml}$ of water (CO group) or a drink containing CHO and milk whey protein (CHO-P group) respectively, 6 and 3 hours before operation. Blood samples were collected before surgery and 24 hours afterwards for biochemical assays. The endpoints of the study were the insulin resistance (IR), the prognostic inflammatory and nutritional index (PINI) and the C-reactive protein (CRP)/albumin ratio. A 5\% level for significance was established.
\end{abstract}

Results: There were no anesthetic or postoperative complications. The post-operative IR was lower in the CHO-P group when compared with the CO group $(2.75 \pm 0.72$ vs $5.74 \pm 1.16 ; p=0.03)$. There was no difference between the two groups in relation to the PINI. The CHO-P group showed a decrease in the both CRP elevation and CRP/ albumin ratio $(p<0.05)$. The proportion of patients who showed CRP/albumin ratio considered normal was significantly greater $(\mathrm{p}<0.05)$ in the CHO-P group (87.5\%) than in the CO group (33.3\%).

Conclusions: Shortening the pre-operative fasting using $\mathrm{CHO}$ and whey protein is safe and reduces insulin resistance and postoperative acute phase response in elective moderate operations.

Trial registration: ClinicalTrail.gov NCT01354249

Keywords: preoperative fasting, insulin resistance, carbohydrates, whey protein, inflammatory response

\section{Introduction}

Perioperative care has been the subject of a number of studies in the last decade. The benefits of 6-8 hours of preoperative fasting in order to reduce the risk of pulmonary aspiration of gastric content [1] has been recently questioned by various studies [2-4]. Despite

\footnotetext{
* Correspondence: aguilar@terra.com.br

'Department of Surgery, Julio Muller University Hospital, Federal University of Mato Grosso, Brazil

Full list of author information is available at the end of the article
}

this, the "nothing by mouth after midnight" routine is still prescribed by many surgeons and anesthesiologists due to outdated concepts and paradigms [5]. In addition, conventional fasting is aggravated by the fact this it is usually prolonged. When added up, pre-operative fasting can be excessively long lasting form 10 up to 16 hours [6]. This may impair the recovery of patients since the organic response to surgical trauma is enhanced by the prolonged period of fasting.

\section{Biomed Central}

(c) 2011 Perrone et al; licensee BioMed Central Ltd. This is an Open Access article distributed under the terms of the Creative Commons Attribution License (http://creativecommons.org/licenses/by/2.0), which permits unrestricted use, distribution, and reproduction in any medium, provided the original work is properly cited. 
Hyperglycaemia is a sensitive marker of the metabolic response to trauma, and it is due to a reduction of the peripheral action of insulin mediated by contra-regulating hormone action. These hormones stimulated glycogen and lipid catabolism thus stimulating hepatic neoglycogenesis as well as increasing peripheral resistance to insulin [7]. This response is related to the magnitude of the trauma as well as the duration of preoperative fasting [7-9].

Trauma, as well as other causes of injury including fasting, induces a response typified by the release of inflammatory mediators. These mediators, including interleukins (IL) 1, 2, 6 and the tumor necrosis factor (TNF), appear to be related to the metabolic alterations found early after injury [8,9]. A significant increase in the IL- 6 plasma concentration thirty minutes after surgery confirms that this cytokine is an early and sensitive marker of tissue lesion, and is related to the trauma magnitude and duration [10]. Besides IL-6, acute-phase proteins such as C-reactive protein (CRP), and negatives such as albumin and pre-albumin, may be useful as predictors of post-operative infection [8]. Within this context, the prognostic inflammatory and nutritional index (PINI) proposed by Ingenbleek and Carpentier has been used and validated to predict risks related to morbidity and mortality. The PINI uses a combination of two positive acute-phase proteins (CRP and $\alpha$-1-acid glycoprotein) and two negatives (albumin and pre-albumin) [11]. Some studies have shown that formulas using acute-phase proteins such as the PCR/albumin ratio may predict risks for hospitalized patients [12,13].

To abbreviate preoperative fasting, beverages containing carbohydrates have been used and recommended [4,14-16]. Recently formulas containing either proteins or amino acids in addition to the carbohydrate-enriched drink have been proposed. These new formulas may improve post-operative muscle strength, reduce fatigue, anxiety and discomfort as well as lowering the endocrine-metabolic response to trauma [15]. The use of glutamine in the composition of these drinks improved the hepatic and mitochondrial metabolic response in two recent studies $[16,17]$.

Whey protein contains a high level of essential amino acids especially branched-chain amino acids [18]. The branched-chain amino acids (leucine, isoleucine, and valine) are rapidly used by skeletal muscle during stress and highly stimulate protein synthesis $[19,20]$. In addition, they are precursors of endogenous synthesis of glutamine, the main energy source for enterocytes [19]. Whey protein has also been described as an excellent source of cysteine, a precursor of glutathione synthesis, which acts as an endogenous antioxidant [21]. Moreover, whey protein has a high degree of digestibility and rapid absorption in the small bowel [22]. No study so far has aimed to examine the possible benefits of whey protein in the composition of preoperative drinks. Therefore, the aim of this study was to investigate whether the shortening of pre-operative fasting using a solution containing carbohydrates and whey proteins may alter the organ ic response to trauma, focusing on insulin resistance and acute-phase response in elective moderate operations.

\section{Materials and methods}

This was a randomized, double-blind, clinical study carried out at the Julio Muller University Hospital (Mato Grosso State, Brazil). The study was approved by the hospital Research Ethics Committee registered under number 635/CEP-HUJM/09 and is in accordance with the ethics principals set out in the Helsinki Declaration (2000), and meets Brazilian national legal specifications. The study was registered in ClinicalTrails.gov under the number NCT01354249. External monitoring of the study was carried out by the Research Ethics Committee of the Julio Muller Hospital.

Inclusion criteria includes adults (18-65 years-old), of both sexes, and candidates to elective moderate operations such as open cholecystectomy, laparoscopic cholecystectomy and unilateral repair of inguinal hernia). Exclusion criteria were acute cholecystitis, diabetes mellitus, chronic kidney failure, chronic liver disease ot serum bilirubin greater than $2 \mathrm{mg} / \mathrm{dL}$, body mass index (BMI) above $35 \mathrm{Kg} / \mathrm{m}^{2}$, American Anesthesiologists Association (ASA) score above 2, gastro-esophageal reflux, gastroparesis or intestinal obstruction. Patients with any non-compliance with the study protocol, or who had associated operations, or presented significant intraoperative occurrences, or experienced prolonged operations (lasting more than 3 hours) were also excluded.

Patient randomization was carried out on admission to the hospital using random numbers issued by a computer program [23]. For the randomization the precepts of the CONSORT flow diagram were followed [24].

The patients were randomized into two groups: the carbohydrate-protein group ( $\mathrm{CHO}-\mathrm{P})$ and the control group (CO). The patients were given a specific drink to their group on the evening prior to surgery and three hours before the operation. The CHO-P group received $474 \mathrm{ml}$ (evening drink) or $237 \mathrm{ml}$ ( $3 \mathrm{~h}$ prior to operation drink) of a solution containing $14 \%$ whey protein $(100 \%$ lactoalbumin), $86 \%$ carbohydrates (45\% maltodextrine and $55 \%$ sucrose) and $0 \%$ lipids (Resource ${ }^{\circledR}$ Breeze Nestlé, São Paulo, Brasil) and the CO group received the same volume of water. All the patients fasted for solids for 6 hours from the operation.

On the day of the surgery and on the first postoperative day blood samples were collected for glucose, 
insulin, triglycerides, albumin, pre-albumin, CRP, and $\alpha$ 1 -acid glycoprotein $(\alpha-1-G A)$ assays. Preoperative samples were collected at the infirmary approximately one hour before the patient was sent to the surgical center.

The HOMA-IR (Homeostasis Model Assessment-Insulin Resistance) equation was used as proposed by Matthews et al [25] to assess insulin resistance according to the formula: HOMA-IR= insulin $(\mu \mathrm{U} / \mathrm{mL}) \times$ glycaemia $(\mathrm{mg} / \mathrm{dL}) / 405$. To assess inflammatory activity the PINI $($ CRP $(\mathrm{mg} / \mathrm{L}) \times \alpha-1-G A(\mathrm{mg} / \mathrm{L}) /$ albumin $(\mathrm{g} / \mathrm{L}) \times$ prealbumin $(\mathrm{mg} / \mathrm{L})$ and the $\mathrm{CRP} /$ albumin ratio were used [11].

Nutritional status was assessed by BMI and subjective global assessment [26]. The patients received intraoperatively a single dose of $2 \mathrm{~g}$ of intravenous cefazolin and were hydrated with $1000-1500 \mathrm{ml}$ of Ringer's lactate during immediate postoperative period. Dipyrone (500 mg IV every 6 hours) was prescribed for pain and antiemetics were used only when necessary.

\section{Statistical Method}

The sampling calculation was based on a previous study [27]. A quantity of 8 cases in each study branch was judged to be sufficient to ensure $80 \%$ power (beta error) and $5 \%$ significance (alpha error) expecting a difference in $50 \%$ in in the insulin resistance (Homa equation). All the continuous data were initially analysed for homogeneity by the Levene test and for normality by the Kolmogorov-Smirnov test. The Student $t$ test or MannWhitney test was then applied accordingly. A cut-off for normality was for serum CRP ( $48 \mathrm{mg} / \mathrm{L})$ and CRP/albumin ratio (11) based on the overall mean of the data plus 1 standard deviation. A significance level of $5 \%$ (p $<0.05$ ) was established. The data were presented as a mean and standard deviation or as a median and variance. All the calculations were made on a computer using the Statistical Package for the Social Sciences (SPSS) for Windows 11. 0.

\section{Results}

Twenty six patients were eligible for the study and randomized to either $\mathrm{CO}$ group $(\mathrm{n}=12)$ or CHO-P group $(\mathrm{n}=14)$. Nine patients were excluded for different causes remaining eight patients in the $\mathrm{CHO}-\mathrm{P}$ group and nine in the $\mathrm{CO}$ group. The flowchart of the study can be seen in Figure 1.

All the patients were classified as eutrophic. There were no deaths or postoperative complications in the two groups. The demographic and clinical characteristics of the patients can be seen in table 1 .

None of the patients presented anesthetic complications. Patients who received CHO-P beverage had no intolerance such as nausea or vomiting preoperatively.

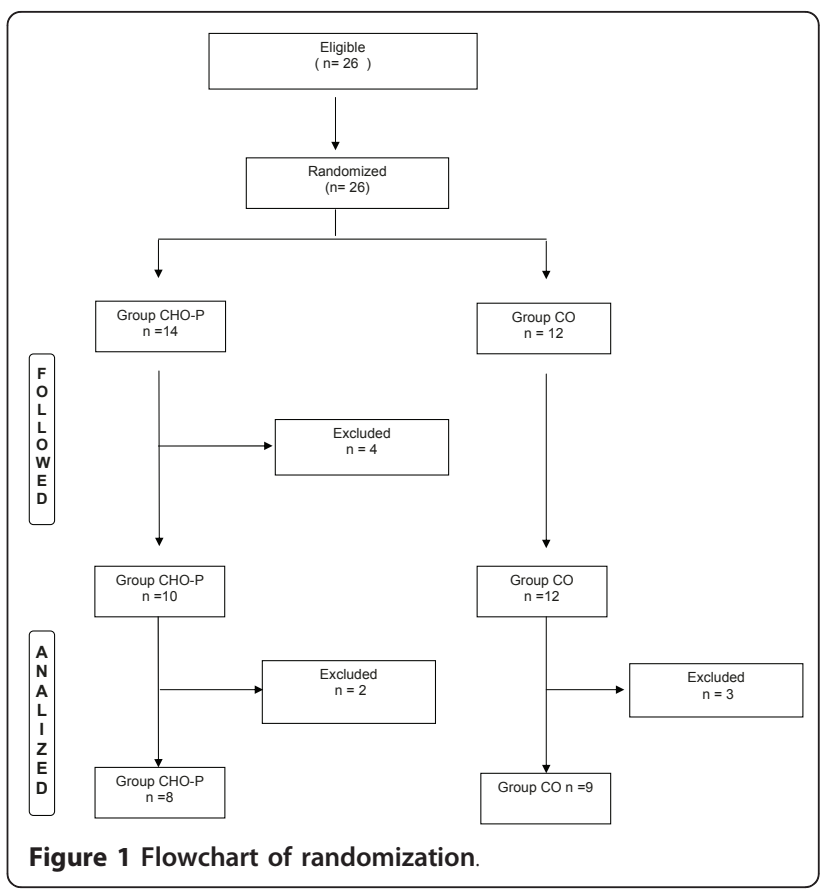

Table 1 Demographics and clinical aspects of the patients in the two groups.

\begin{tabular}{|c|c|c|c|}
\hline Variable & $\begin{array}{l}\text { Group CO } \\
\text { N (\%) }\end{array}$ & $\begin{array}{l}\text { Group CHO-P } \\
\mathrm{N}(\%)\end{array}$ & $\mathbf{p}$ \\
\hline \multicolumn{4}{|l|}{ Sex } \\
\hline Male & $3(33.3)$ & $3(37.5)$ & 1.00 \\
\hline Female & $6(66.7)$ & $5(62.5)$ & \\
\hline Age (years) (mean \pm SEM) & $41.0 \pm 4.0$ & $35.0 \pm 6.0$ & 0.41 \\
\hline \multicolumn{4}{|l|}{ Type of operation } \\
\hline Open cholecystectomy & $6(66.7)$ & $4(50)$ & 0.71 \\
\hline Video-cholecystectomy & $2(22.2 \%)$ & $2(25,0 \%)$ & \\
\hline Inguinal hérnia repair & $1(11,1 \%)$ & $2(25,0 \%)$ & \\
\hline $\begin{array}{l}\text { Duration of the operation (min) } \\
\text { (mean } \pm \text { SEM) }\end{array}$ & $99.0 \pm 11.0$ & $94.0 \pm 8.0$ & 0.52 \\
\hline \multicolumn{4}{|l|}{ Type of anaesthesia } \\
\hline General & $4(44.4)$ & $3(37.5)$ & 0.78 \\
\hline Epidural blockage & $2(22.2)$ & $3(37.5)$ & \\
\hline General+ epidural blockage & $3(33.3)$ & $2(25)$ & \\
\hline $\begin{array}{l}\text { Duration of fasting (min) } \\
\text { (mean } \pm \text { SEM) }\end{array}$ & $1014 \pm 38$ & $264 \pm 9$ & 0.001 \\
\hline \multicolumn{4}{|l|}{ Nutritional status } \\
\hline Eutrophic & $9(100)$ & $8(100)$ & 1.00 \\
\hline $\mathrm{BM}{ }^{*}\left(\mathrm{~kg} / \mathrm{m}^{2}\right)($ mean $\pm \mathrm{SEM})$ & $30.7 \pm 2.1$ & $26.9 \pm 1.5$ & 0.19 \\
\hline \multicolumn{4}{|l|}{ ASA score $e^{+}$} \\
\hline 1 & $3(33.3)$ & $7(87.5)$ & 0.05 \\
\hline$\|$ & $6(66.7)$ & $1(12.5)$ & \\
\hline $\begin{array}{l}\text { Length of hospital stay (median } \\
\text { and range) }\end{array}$ & $1(1-2)$ & $1(1-2)$ & 0.40 \\
\hline
\end{tabular}


Glycaemia, insulin and insulin resistance

The CO group showed greater serum insulin (19.9 \pm $3,99$ versus $10.7 \pm 2.9 \mu \mathrm{U} / \mathrm{mL} ; \mathrm{p}=0.049)$ and insulin resistance $(5.7 \pm 1.1$ versus $2.7 \pm 0.7 ; \mathrm{p}=0.03)$ when compared to $\mathrm{CO}$ group postoperatively. The insulin resistance alterations before and after surgery were found to be significantly higher in the $\mathrm{CO}$ group as can be seen in Figure 2. There was also a trend to show higher glycaemia $(115 \pm 6 \mathrm{mg} / \mathrm{dL})$ in this group as can be seen in table 2. Preoperatively the values of insulin resistance $(5.3 \pm 6.6$ vs. $0.96 \pm 0.27)$, glycaemia (103 \pm $7 \mathrm{mg} / \mathrm{dL}$ vs $85 \pm 5 \mathrm{mg} / \mathrm{dL})$ and insulinemia (19.5 \pm $5.1 \mu \mathrm{U} / \mathrm{mL}$ vs. $4.4 \pm 1.2 \mu \mathrm{U} / \mathrm{mL}$ ) were higher in the $\mathrm{CHO}-\mathrm{P}$ group than in the $\mathrm{CO}$ group.

In the comparison between the alterations occurring in the two groups, between pre and post operative, significant differences were found in the three parameters. Thus, there was a significant increase $(\mathrm{p}<0.05)$ in glycaemia, insulinemia and insulin resistance increase in the $\mathrm{CO}$ group and a reduction in the $\mathrm{CHO}-\mathrm{P}$ group which can be clearly seen in table 3 .

Figure 3 mirrors the percentage variance that occurred with glycaemia, insulinemia and in the HOMA-IR before and after surgery. A significant difference was found between the two groups.

\section{Inflammatory response}

The CRP values in the pre and post-operative periods for the two groups can be seen in table 4. Serum CRP increased significantly $(\mathrm{p}<0.01)$ in the two groups. However, postoperative serum CRP was significantly higher in $\mathrm{CO}$ group. There were no cases in the $\mathrm{CHO}-\mathrm{P}$ group of values above the cut-off point as shown in table $5(\mathrm{p}=0.03)$.

Preoperatively serum $\alpha$-1-acid glycoprotein was greater $(\mathrm{p}=0.03)$ in the CHO-P group $(98.1 \pm 8.9 \mathrm{mg} / \mathrm{dL})$ than in the $\mathrm{CO}$ group $(75.8 \pm 3.9 \mathrm{mg} / \mathrm{dL})$. However, there was

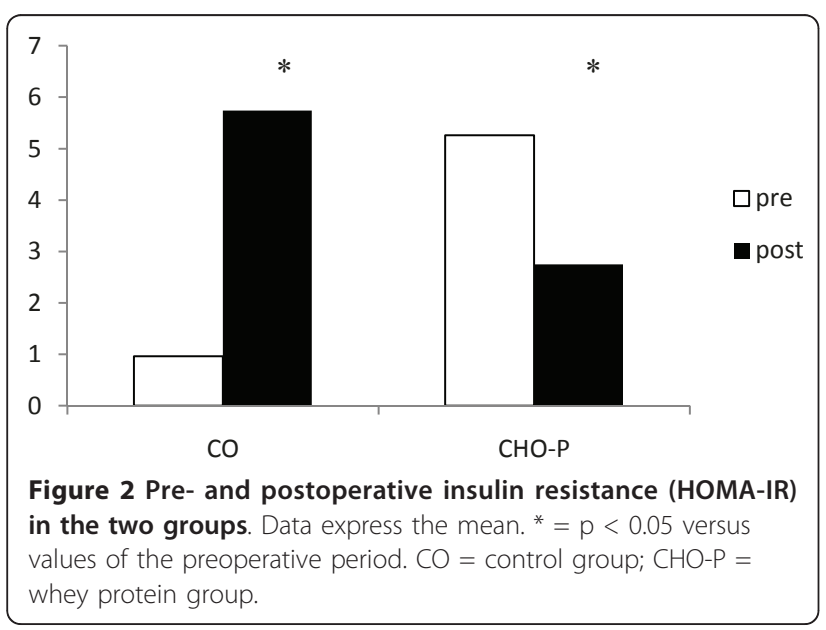

Table 2 Mean and standard error of the mean of postoperative serum glycaemia, insulin, and insulin resistance (HOMA-IR) in the two groups

\begin{tabular}{lccc}
\hline Variable & Group CO & Group CHO-P & P \\
\hline HOMA-IR & $5.74 \pm 1.16$ & $2.75 \pm 0.72$ & 0.03 \\
Insulin & $19.9 \pm 3.9$ & $10.7 \pm 2.9$ & 0.05 \\
Glycaemia & $115.0 \pm 6.0$ & $105.0 \pm 8.0$ & 0.09 \\
\hline
\end{tabular}

$\mathrm{CO}=$ control group; $\mathrm{CHO}-\mathrm{P}=$ whey protein group.

no significant difference between the groups $(\mathrm{p}=0.57)$ at the postoperative period, as can be seen in table 4. Serum $\alpha$-1-acid glycoprotein significantly increased only the CO group ( $<<0.01)$.

There were no differences in the albumin values between the two groups in both the pre $(\mathrm{p}=0.53)$ and post-operative assays $(p=0.29)$. However $\mathrm{CO}$ group showed a significant decrease from pre- to postoperative values $(\mathrm{p}<0.01)$.

There was no difference in serum pre-albumin levels in the two groups. The CRP/albumin ratio increased after the operation in both groups. However the number of cases with CRP/albumin ratio above the cutoff was greater in $\mathrm{CO}$ groups when compared to $\mathrm{CHO}-\mathrm{P}$ group $(\mathrm{p}=0.04)$ as shown in table 6 .

\section{Discussion}

The overall results showed that the postoperative peripheral insulin resistance was reduced with the abbreviation of fasting with a beverage containing carbohydrates plus whey protein. Insulin resistance is a transitory phenomenon restricted to the first few days after surgery and lasting up to three weeks in cases of elective abdominal operations with no complications [10]. This metabolic state is very similar to type II diabetes whereby glucose capture by cells is reduced due to the incapacity of the GLUT-4 transporter to carry out this function and, consequently, the production of glycogen is reduced [10]. Simultaneously, there is an increase in the endogenous glucose that may become a serious risk factor for increase morbidity [28]. Thus the findings of increased insulin resistance after the operation in the group submitted to prolonged fasting was expected. This result contrasts with the opposite evolution seen in

Table 3 Mean and standard error of the mean of the difference between preoperative and postoperative values of serum glycaemia, insulin, and insulin resistance (HOMA-IR) in the two groups

\begin{tabular}{lccc}
\hline Variable & Grupo CO & Grupo CHO-P & p \\
\hline HOMA-IR & $4.8 \pm 1.1$ & $-2.5 \pm 1.5$ & $\mathrm{p}=0.001$ \\
Insulin & $15.5 \pm 3.8$ & $-8.8 \pm 4.6$ & $\mathrm{p}<0.001$ \\
Glycaemia & $30.0 \pm 7.3$ & $1.6 \pm 12.1$ & $\mathrm{p}=0.036$ \\
\hline
\end{tabular}

$\mathrm{CO}=$ control group; $\mathrm{CHO}-\mathrm{P}=$ whey protein group. 


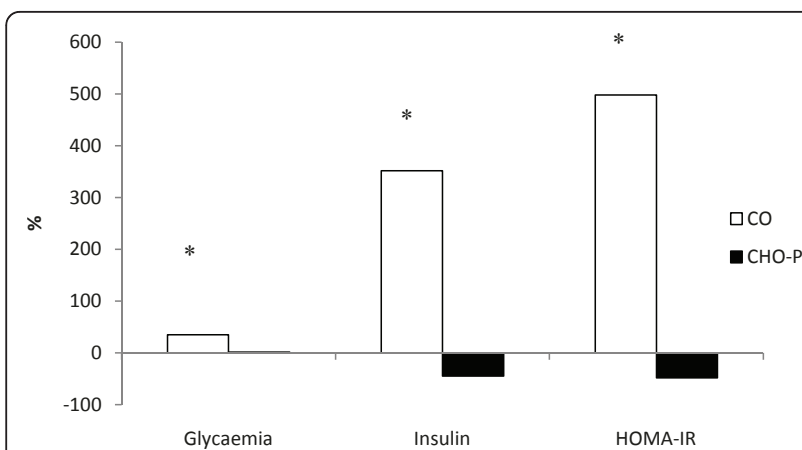

Figure 3 Percentage changes between pre- and postoperative values of serum glycaemia, insulin, and insulin resistance (HOMA-IR) in the two groups. ${ }^{*} p<0.05$ versus group CHO-P. CO = control group; $\mathrm{CHO}-\mathrm{P}=$ whey protein group.

the CHO-P groups and was similar in other studies $[27,29]$. At the preoperative phase the CHO-P group presented an increased HOMA-IR in comparison to CO group. However this was expected because blood samples were collected one hour before the patients had entered the operating room and after they had ingested the preconditioning beverage.

Proteins and amino acids may reduce the insulin response in some clinical conditions such as obesity and type II diabetes [30,31]. Whey protein is a rich source of essential amino acids which are the most important regulators of this response [32]. Indeed, the addition of whey protein to a carbohydrate drink improved the insulin response compared with the ingestion of carbohydrates only [33]. However the findings of this study should be seen with the necessary caution because there was not a group with only whey protein and thus the results seen here may theoretically reflected only the $\mathrm{CHO}$ effect.

There was a delay from the programmed preoperative fasting time in both the two groups. Indeed CHO-P patients were operated on after approximately $4 \mathrm{~h}$ of fasting and $\mathrm{CO}$ group after $17 \mathrm{~h}$. This frequent delay was reported earlier by our group [6,27]. It should be in the mind of both the surgeon and the anesthesiologist
Table 5 Postoperative serum C-reactive protein (CRP) below or above the cutoff point $(48 \mathrm{mg} / \mathrm{L})$ in the two groups

\begin{tabular}{lcc}
\hline CRP & $\begin{array}{c}\text { Group CO } \\
\mathbf{N}(\%)\end{array}$ & $\begin{array}{c}\text { Group CHO-P } \\
\mathbf{N}(\%)\end{array}$ \\
\hline Above & $5(55.5)^{*}$ & $0(0)$ \\
Below & $4(44.5)$ & $8(100)$ \\
Total & 9 & 8 \\
\hline
\end{tabular}

$\mathrm{CO}=$ control group; $\mathrm{CHO}-\mathrm{P}=$ whey protein group.

${ }^{*} p=0,03$

that this extended fasting is most prone to occur and therefore should be audit in every institution due to the harm that it may cause to the patients.

The type of $\mathrm{CHO}$ contained in the beverage tested was a mixture of maltodextrine and sucrose. Maltodextrin is a sweat, easily digested carbohydrate made from corn starch. It contains small chains of several dextrose molecules held together by very weak hydrogen bonds. This makes its absorption slower than sucrose and thus elicits maltodextrin as an excellent $\mathrm{CHO}$ for preoperative drinks. The solution containing both maltodextrine and sucrose may enhance the activation of more transport mechanisms in the intestinal lumen and for this reason may facilitate faster energy uptake and hydration [34].

CRP is a positive acute-phase protein and its levels well correlate with the inflammation intensity and may predict postoperative complications [1,8]. In opposition a decrease of negative acute-phase protein such as albumin and prealbumin after trauma is expected due to the inhibition of their synthesis by the pro-inflammatory cytokines [7]. The findings have shown that the inflammatory response to trauma was less intense in the intervention group. Significantly changes of serum albumin levels and serum $\alpha-1-$ GA were only found in the $C O$ group. Besides this, the proportion of cases with abnormal CRP levels was greater in the control group. These findings are relevant and suggest that a lower inflammatory response was presented in the group fed with carbohydrates plus whey protein 3-4 h prior to surgery.

Table 4 Mean and standard error of the mean of various inflammatory markers in the two groups

\begin{tabular}{|c|c|c|c|c|c|c|}
\hline \multirow[t]{3}{*}{ Variable } & \multicolumn{6}{|c|}{ Period and groups } \\
\hline & \multicolumn{3}{|c|}{ Preoperative } & \multicolumn{3}{|c|}{ Postoperative } \\
\hline & $\mathrm{CO}$ & CHO-P & $p$ & $\mathrm{CO}$ & CHO-P & $p$ \\
\hline Albumin (g/dL) & $4,15 \pm 0,13$ & $4,26 \pm 0,09$ & 0,53 & $3,82 \pm 0,12$ & $4,02 \pm 0,14$ & 0,29 \\
\hline Prealbumin (mg/dL) & $0,25 \pm 0,02$ & $0,22 \pm 0,01$ & 0,33 & $0,26 \pm 0,05$ & $0,21 \pm 0,02$ & 0,43 \\
\hline CRP $(\mathrm{mg} / \mathrm{L})$ & $7,4 \pm 1,27$ & $6,25 \pm 0,90$ & 0,46 & $40,12 \pm 10,04$ & $27,37 \pm 4,76$ & 0,29 \\
\hline$\alpha-1-G A(m g / d L)$ & $75,87 \pm 3,94$ & $98,1 \pm 8,9$ & 0,03 & $90,5 \pm 3,9$ & $105,8 \pm 6,5$ & 0,57 \\
\hline PINI & $0,63 \pm 0,16$ & $0,76 \pm 0,22$ & 0,64 & $5,98 \pm 2,05$ & $3,93 \pm 1,01$ & 0,40 \\
\hline CRP/albumin ratio & $1,81 \pm 0,32$ & $1,46 \pm 0,20$ & 0,38 & $10,99 \pm 2,89$ & $6,97 \pm 1,35$ & 0,25 \\
\hline
\end{tabular}


Table 6 Postoperative serum C-reactive protein (CRP)/ albumin ratio below or above the cutoff point (11) in the two groups

\begin{tabular}{lcc}
\hline CRP/albumin ratio & $\begin{array}{c}\text { Group CO } \\
\mathbf{N}(\%)\end{array}$ & $\begin{array}{c}\text { Group CHO-P } \\
\mathbf{N}(\%)\end{array}$ \\
\hline Above & $6(66.7)^{*}$ & $1(12.5)$ \\
Below & $3(33.3)$ & $7(87.5)$ \\
Total & 9 & 8 \\
\hline
\end{tabular}

$\mathrm{CO}=$ control group; $\mathrm{CHO}-\mathrm{P}=$ whey protein group.

$\therefore$, $\mathrm{p}=0,04$

The genetic expression of $\alpha-1-\mathrm{GA}$ is controlled by a combination of the main inflammatory mediators such as glycocorticoids and a network of cytokines [35]. At the preoperative sample we found an increased serum $\alpha-1-G A$ in the CHO-P group when compared to CO group. This result seen in whey protein fed patients was probably due to the early supply of lactoalbumin. Genes that codify the whey protein are similar to the genes that codify the $\alpha-1-$ GA [36]. Thus, the supply of whey protein, especially lactoalbumin may have contributed to the increase in the $\alpha-1-$ GA concentration level. However, only $\mathrm{CO}$ group showed a significant increase in serum $\alpha-1$-GA between the pre- and postoperative sam [ples suggesting a greater inflammatory response. However, the PINI calculation that uses the values of serum $\alpha-1-G A$ was probably biased.

One possible criticism for this study is the small number of cases. However, we performed sample calculation aiming for a power analysis above $80 \%$. If a difference in treatment can be seeing with small sample (but with sufficient power analysis) adding subjects may only increase duration and costs of the study. We believe that samples should be large enough to detect possible differences, reasonable enough to be feasible, and small enough to detect efficient therapies. Another possible criticism is that ASA score was higher in $\mathrm{CO}$ group. However we excluded patients with important chronic diseases and only elicited in the study patients with ASA score I and II. We do not believe that this finding could compromise the results.

In summary the shortening of preoperative fasting to 3 hours using a drink containing carbohydrates and whey protein not only have minimized the postoperative insulin resistance but also reduced the magnitude of the acute phase inflammatory response. Thus we concluded that the abbreviation of preoperative fasting with carbohydrates plus whey protein is safe and diminishes the organic response after moderate operations in general surgery.

\section{Funding}

This study was funded by the Fundação de Amparo à Pesquisa de Mato Grosso and the Coordenação de Aperfeiçoamento de Pessoal de Nivel Superior

\section{Acnowledgements}

This study was funded by the FAPEMAT (Fundação de Amparo à Pesquisa de Mato Grosso) and by the CAPES (Coordenação de Aperfeiçoamento de Pessoal de Nivel Superior).

\section{Author details}

${ }^{1}$ Department of Surgery, Julio Muller University Hospital, Federal University of Mato Grosso, Brazil. ${ }^{2}$ Rodovia Helder Candia, Condominio Country 15 78048150, Cuiabá, MT, Brazil.

\section{Authors' contributions}

FP - data collection; manuscript drafting and organization; ACSF, IFA, NTA, FSL, TC, and BDO - sequence alignment, laboratory data and acquisition of the data. DBDN, AD, and JEAN - study design and concept; data analysis, manuscript drafting and organization. All authors have read and approved the final version of the manuscript.

\section{Conflicts of interests}

The authors declare that they have no competing interests.

Received: 14 April 2011 Accepted: 13 June 2011

Published: 13 June 2011

\section{References}

1. Mendelson $\mathrm{CL}$ : The aspiration of stomach contents into the lungs during obstetric anesthesia. Am J Obstet Gynecol 1946, 52:191-205.

2. Maltby JR, Sutherland A, Sale GP, Shaffer EA: Preoperative oral fluids: Is a five-hour fast justified prior to elective surgery? Anesth Analg 1986, 65:1112-1116.

3. Strunin L: How long should patients fast before surgery. Time for new guidelines. Br J Anaesth 1993, 70:1-3.

4. Weimann A, Braga M, Harsanyi L, Laviano, Ljungqvist $O$, Soeters $P$, Jauch $K$, Kemen M, Hiesmayr J, Horbach T: ESPEN Guidelines on enteral nutrition: surgery including organ transplantation. Clin Nutr 2006, 25:224-244.

5. McLeod R, Fitzgerald W, Sarr M: Preoperative fasting for adults to prevent perioperative complications. Can J Surg 2005, 48:409-411.

6. Aguilar-Nascimento JE, Salomão AB, Caporossi C, Diniz BN: Clinical benefits after the implementation of a multimodal perioperative protocol in elderly patients. Arq Gastroenterol 2010, 47:178-183.

7. Thorell A, Ljungqvist O, Efendic S, Gutniak M, Häggmark T: Development of postoperative insulin resistance is associated with the magnitude of operation. Eur J Surg 1993, 159:593-599.

8. Gabay C, Kushner I: Acute-phase proteins and other systemic responses to inflammation. N Engl J Med 1999, 340:448-454.

9. Aguilar-Nascimento JE, Marra JG, Slhessarenko N, Fontes CJ: Efficacy of National Nosocomial Infection Surveillance score, acute-phase proteins, and interleukin- 6 for predicting postoperative infections following major gastrointestinal surgery. Sao Paulo Med J 2007, 125:34-41.

10. Yang RD, Moldawer LL, Sakamoto A, Keenan RA, Matthews DE, Young V: Leukocyte endogenous mediators alter protein dynamics in rats. Metabolism 1983, 32:654-660.

11. Ingenbleek $Y$, Carpentier $Y A$ : A prognostic inflammatory and nutritional index scoring critically ill patients. Int J Vitam Nutr Res 1985, 55:91-101.

12. Claxtron B: The prognostic inflammatory and nutritional index in traumatized patients receiving enteral nutrition support. JPEN J Parenter Enteral Nutr 1992, 16:85-86.

13. Corrêa CR, Angeleli AYO, Camargo NR, Barbosa L, Burini RC: Comparação

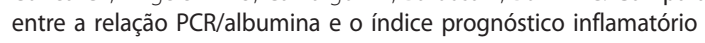
nutricional (IPIN). J Bras Patol Med Lab 2002, 38:183-190.

14. Soreide E, Eriksson LI, Hirlekar G, Eriksson H, Henneberg SW, Sandin R, Raeder J: Pre-operative fasting guidelines: an update. Acta Anaesthesio/ Scand 2005, 49:1041-1047.

15. Henriksen MG, Hessov I, Dela F, Vind Hansen H, Haraldsted V, Rodt AS: Effects of preoperative oral carbohydrates and peptides on postoperative endocrine response, mobilization, nutrition and muscle function in abdominal surgery. Acta Anaesthesiol Scand 2003, 47:191-199.

16. Lobo DN, Hendry PO, Rodrigues G, Marciani L, Totman JJ, Wright JW, Presto T, Gowland P, Spiller RC, Fearon KCH: Gastric emptying of three liquid oral preoperative metabolic preconditioning regimens measured by magnetic resonance imaging in healthy adult volunteers: a randomised double-blind, crossover study. Clin Nutr 2009, 28:636-641. 
17. Awad S, Stephenson MC, Placidi E, Marciani L, Constantin-Teodosiu D, Gowland PA, Spiller RC, Fearon KCH, Morris PG, Macdonald IA, Lobo DN: The effects of fasting and refeeding with a 'metabolic preconditioning' drink on substrate reserves and mononuclear cell mitochondrial function. Clin Nutr 2010, 29:538-544.

18. Haraguchi FK, Abreu WC, Paula H: Proteínas do soro do leite: composição, propriedades nutricionais, aplicações no esporte e benefícios para a saúde humana. Rev Nutr 2006, 19:479-488.

19. Sax HC, Talamini MA, Fischer JE: Clinical use of branched-chain amino acids in liver disease, sepsis, trauma, and burns. Arch Surg 1986, 121:358-366.

20. Nawabi MD, Block KP, Chakrabarti MC, Buse MG: Administration of endotoxin, tumor necrosis factor, or interleukin 1 to rats activates skeletal muscle branched-chain alpha-keto acid dehydrogenase. J Clin Invest 1990, 85:256-263.

21. Bray TM, Taylor CG: Tissue glutathione, nutrition, and oxidative stress. Can J Physiol Pharmacol 1993, 71:746-751.

22. Boirie $Y$, Dangin M, Gachon $P$, Vasson MP, Maubois JL, Beaufrère B: Slow and fast dietary proteins may differently modulate postprandial protein accretion. Proc Natl Acad Sci USA 1997, 9426:14930-14935.

23. GraphPad Software Scientific graphing, curve fitting (non linear regression) \& statistics [homepage]. La Jolla, CA, USA; [http://www. graphpad.com], c1995 [updated in 2009; accessed in jan 22. 2011].

24. Moher D, Schulz KF, Altman DG: The CONSORT statement: revised recommendations for improving the quality of reports of parallel-group randomized trials. Lancet 2001, 357:1191-1194.

25. Matthews DR, Hosker JP, Rudenski AS, Naylor BA, Treacher DF, Turner RC: Homeostasis model assessment: insulin resistance and beta-cell function from fasting plasma glucose and insulin concentrations in man. Diabetologia 1985, 28:412-429.

26. Detsky AS, McLaughlin JR, Baker JP, Johnston N, Whittaker S, Mendelson RA, Jeejeebhoy KN: What is subjective global assessment of nutritional status? JPEN J Parenter Enteral Nutr 1987, 11:8-13.

27. Faria MS, de Aguilar-Nascimento JE, Pimenta OS, Alvarenga LC, DockNascimento DB, Shessarenko N: Preoperative fasting of 2 hours minimizes insulin resistance and organic response to trauma after videocholecystectomy: a randomized, controlled, clinical trial. World J Surg 2009, 33:1158-1164.

28. Hill AG, Hill GL: Metabolic response to severe injury. Br J Surg 1998, 85:884-890.

29. Wang ZG, Wang Q, Wang WJ, Qin HL: Randomized clinical trial to compare the effects of preoperative oral carbohydrate versus placebo on insulin resistance after colorectal surgery. Br J Surg 2010, 97:317-327.

30. Holt SH, Brand Miller JC, Petocz P: Interrelationships among postprandial satiety, glucose and insulin responses and changes in subsequent food intake. Eur J Clin Nutr 1996, 50:788-797.

31. Manders RJ, Wagenmakers AJ, Koopman R, Zorenc AH, Menheere PP, Schaper NC, Saris WH, van Loon LJ: Co-ingestion of a protein hydrolysate and amino acid mixture with carbohydrate improves plasma glucose disposal in patients with type 2 diabetes. Am J Clin Nutr 2005, 821:76-83.

32. Floyd JC Jr, Fajans SS, Conn JW, Knopf RF, Rull J: Stimulation of insulin secretion by amino acids. J Clin Invest 1966, 459:1487-1502.

33. van Loon LJ, Saris WH, Verhagen $H$, Wagenmakers AJ: Plasma insulin responses after ingestion of different amino acid or protein mixtures with carbohydrate. Am J Clin Nutr 2000, 721:96-105.

34. Shi X, Summers RW, Schedl HP, Flanagan SW, Chang R, Gisolfi CV: Effects of carbohydrate type and concentration and solution osmolality on water absorption. Med Sci Sports Exerc 1995, 27:1607-1615.

35. Fournier T, Medjoubi NN, Porquet D: Alpha-1-acid glycoprotein. Biochim Biophys Acta 2000, 1482:157-171.

36. Ali S, Clark AJ: Characterization of the gene encoding ovine betalactoglobulin. Similarity to the genes for retinol binding protein and other secretory proteins. J Mol Biol 1988, 199:415-426.

doi:10.1186/1475-2891-10-66

Cite this article as: Perrone et al:: Effects of preoperative feeding with a whey protein plus carbohydrate drink on the acute phase response and insulin resistance. A randomized trial. Nutrition Journal 2011 10:66.

\section{Submit your next manuscript to BioMed Central and take full advantage of:}

- Convenient online submission

- Thorough peer review

- No space constraints or color figure charges

- Immediate publication on acceptance

- Inclusion in PubMed, CAS, Scopus and Google Scholar

- Research which is freely available for redistribution

Submit your manuscript at www.biomedcentral.com/submit
Biomed Central 